\title{
Determinants of adult odonate community structure at several spatial scales: effects of habitat type and landscape context
}

\author{
Wade B. Worthen ${ }^{\mathrm{a} *}$ and Mara G. Chamlee ${ }^{\mathrm{b}}$ \\ ${ }^{a}$ Biology Department, Furman University, Greenville, SC, USA; ${ }^{b}$ Department of Human Dimensions of \\ Natural Resources, Colorado State University, Fort Collins, CO, USA
}

(Received 5 March 2020; final version received 14 July 2020)

\begin{abstract}
Dragonflies (Insecta: Odonata) use both aquatic and terrestrial ecosystems, and the abundance and diversity of odonates should be good indicators of habitat integrity. To determine which environmental variables affect odonates, we sampled adult dragonflies three times at 12 sites in Pickens and Greenville Counties, SC, USA, in different habitats, at different spatial scales, across a landscape gradient from intact forest to urban locations. At each site, we established two $2 \mathrm{~m} \times 20 \mathrm{~m}$ plots along the shoreline of each aquatic habitat. We sampled dragonflies in ten $2 \mathrm{~m} \times 2 \mathrm{~m}$ subplots/plot, described the vegetation and substrate in these subplots and adjacent aquatic subplots, and measured the percent cover of different landforms within $500 \mathrm{~m}$ of each plot center. Using nested ANOVA and Akaike information criteria models, habitat type and correlating environmental variables (substrate type and bank vegetation) were the best predictors of community structure at all spatial scales. Streams and rivers had fewer individuals and species than lakes, and had a nested subset of species found in lake communities. Landscape elements were also important, with indices declining as barren land and grasslands increased. At the largest scale, anthropogenic changes to the landscape had mixed effects. Small habitats isolated in urban areas had a significantly depauperate, nested subset of species found in communities inhabiting larger natural areas. However, odonate abundance and diversity was highest at human-made lakes and ponds, suggesting that these anthropogenic features help maintain odonate communities.
\end{abstract}

Keywords: dragonfly; community ecology; nestedness; anthropogenic effects; Odonata

\section{Introduction}

Dragonflies (Insecta: Odonata) can be effective indicators of habitat integrity (Chovanec \& Waringer, 2001; Golfieri, Hardersen, Maiolini, \& Surian, 2016; Oertli, 2008; Oliviera-Júnior et al., 2015; Renner, Sahlén, \& Périco, 2016; Silva, De Marco, \& Resende, 2010), making them useful for questions in applied ecology and conservation biology (Bried \& Samways, 2015; Córdoba-Aquilar, 2008; Villalobos-Jiménez, Dunn, \& Hassall, 2016). With aquatic larvae and terrestrial adults, their abundance and diversity is usually greater in intact, heterogeneous, natural ecosystems that contain ponds, streams, lakes, forests, and meadows than in simplified, human-altered landscapes (Dolný \& Harabiš, 2012; Foote \& Rice Hornung, 2005; Kayoda, Suda, Nishihiro, \& Washitani, 2008; Luke et al., 2017; Remsburg, 2007; Remsburg \& Turner, 2009; Sahlén and Ekestubbe, 2001). Although many species are fairly tolerant of waterborne pollutants - one (Brachymesia contaminata (Fabricius)) is even an indicator species of contaminated

*Corresponding author: Email: wade.worthen@furman.edu 
water (Palita, Jena, \& Debat, 2016) - several species are sensitive to pollution and are indicators of good water quality (Stoks, Debecker, Van, \& Janssens, 2015). And, like many organisms, odonates are sensitive to reductions in habitat size and connectivity (De Marco, Nóbrega, de Souza, \& Neiss, 2015; Sato, Kohmatsu, Yuma, \& Tsubaki, 2008). They even appear to be model taxa for studying the effects of climate change (Bush, Theischinger, Nipperess, Turak, \& Hughes, 2013; Collins \& McIntyre, 2017; Hassall, 2015). As such, dragonflies are ideal organisms for monitoring a wide range of anthropogenic impacts on natural systems (Chovanec \& Waringer, 2001; Dolný Harabiš, Bárta, Lhota, \& Drozd, 2013; Hafiane et al., 2016; Simaika \& Samways, 2009; Simaika, Samways, \& Frenzel, 2016; Worthen, 2003).

However, because different species use such a wide range of freshwater habitats and terrestrial environments, it is often difficult to determine which variables are most important to maintaining a single species, a local community, or a regional assemblage. In addition, different factors are important determinants at different scales (Oliveira-Júnior, Dias-Silva, Teodósio, \& Juen, 2019). Some species and communities respond to variation on a small scale, from meters to tens of meters. For example, the density of Aeshna viridis L. larvae - an endangered species that uses only one host plant (Stratiotes aloides) which is declining across Europe - correlates with patch size of the host plant on a scale of 1-100 $\mathrm{m}^{2}$ (Suhonen, Suutari, Kaunisto, \& Krams, 2013). Remsburg and Turner (2009) found that the abundance or species richness of odonate larvae and adults were positively affected by the presence of aquatic macrophytes and tall riparian plants in $\mathrm{m}^{2}$ plots, and Foote and Rice Hornung (2005) found that dragonfly diversity declined with a decline in the height of both aquatic vegetation (for emergence) and upland vegetation (for roost sites) caused by cattle trampling around prairie potholes. Other parameters that affect the abundance and composition of adult dragonfly communities on a small scale include the type and heterogeneity of aquatic and terrestrial vegetation (Goertzen \& Suhling, 2013; Niba \& Samways, 2006; Schindler, Fesl, \& Chovanec, 2003), the presence of detritus (Brasil, Batista, Giehl, Valadão, Santos, \& Dias-Silva, 2014), and light availability (Clark \& Samways, 1996; Remsburg, Olson, \& Samways, 2008).

On a larger scale, Kadoya et al. (2008) demonstrated that diversity was higher in landscapes with forest elements than those without. Several studies in the tropics confirm that clearing rainforest riparian zones for road-building or agriculture has a dramatic negative impact on sensitive zygopteran species (Brasil et al., 2014; Carvalho, Pinto, Oliveira-Júnior, \& Juen, 2013; Monteiro-Júnior, Couceiro, Hamada, \& Juen, 2013; Monteiro-Júnior, Juen, \& Hamada, 2014; Oliviera-Júnior et al., 2015; Rodrigues et al., 2016; Seidu, Danquah, Nsor, Kwarteng, \& Lancaster, 2017). However, anthropogenic habitat alteration facilitates some species, notably generalist anisopterans (Luke et al., 2017; Oliviera-Júnior et al., 2015; Seidu et al., 2017). For example, artificial ponds provide additional habitat that can augment natural habitats and help maintain populations (Maynou, Martin, \& Aranda, 2017; Simaika et al., 2016), allowing some European cities to maintain most of the species in a region - even some species of special concern (Goertzen \& Suhling, 2015). Indeed, total species richness in altered environments can surpass richness in natural habitats if the influx of generalist species exceeds declines in sensitive forest specialists (Monteiro-Júnior et al., 2013; Seidu et al., 2017; Goertzen \& Suhling, 2019). So, the effects of anthropogenic changes to the landscape can have varied effects on odonate communities (Nagy et al., 2019), and more studies are warranted to describe impacts in different regions across several spatial scales.

Our study examined the effects of habitat variation on adult dragonfly communities in the Piedmont Ecoregion of South Carolina, USA. This region was previously dominated by forest cover consisting of mixed southern hardwoods, but the region experienced the largest net loss in forest cover in the Eastern USA in the past 40 years due to anthropogenic habitat conversion (Wood \& Quinn, 2016). Wetlands have also been lost, converted to agriculture and urban development (Dahl, 1990; 1999). As such, it is an excellent place to examine the determinants 
of odonate community structure across a variety of lentic and lotic habitats set in a mosaic of natural, suburban, and urban landscapes. We analyzed how adult odonate abundance, species richness, diversity, and community composition varied across habitats at several spatial scales, in order to determine which variables at each scale were most important for the maintenance of healthy and diverse dragonfly communities.

\section{Methods}

\section{Study sites and habitat parameterization at four spatial scales}

We sampled adult odonates at 12 sites in the Piedmont ecoregion of Pickens Co. and Greenville Co., South Carolina, USA (Figure 1). Five sites were large forested landholdings (Ashmore Heritage Trust Preserve, Blue Wall Preserve, Pleasant Ridge County Park, Paris Mountain State Park, and Table Rock State Park), four sites were within the developed urban landscape of Greenville, SC (Joe Jackson Park, McPherson Park, Falls Park, and Cleveland Park), and three sites (Bunched Arrowhead Heritage Preserve, Lake Conestee Nature Preserve, and Furman University) had a more diverse mix of forest and open areas. Adjacent terrestrial and aquatic sampling plots $(2 \mathrm{~m} \times 20 \mathrm{~m})$ were established along the shoreline of pond, lake, stream, and river habitats; in most cases, two sets of plots were placed in each habitat sampled at a site (Figure 2). The habitats were not sampled the same number of times, nor were they distributed equitably across sites (Table 1).

Habitat characteristics were described at four spatial scales from May to June 2017. At the smallest scale, each plot was divided into ten $2 \mathrm{~m} \times 2 \mathrm{~m}$ subplots. Each subplot was photographed from above, and the percent cover of bare ground, turfgrass, herbaceous cover, short woody vegetation $(<2 \mathrm{~m})$, and tall woody vegetation $(>2 \mathrm{~m})$ were measured using Image $\odot$

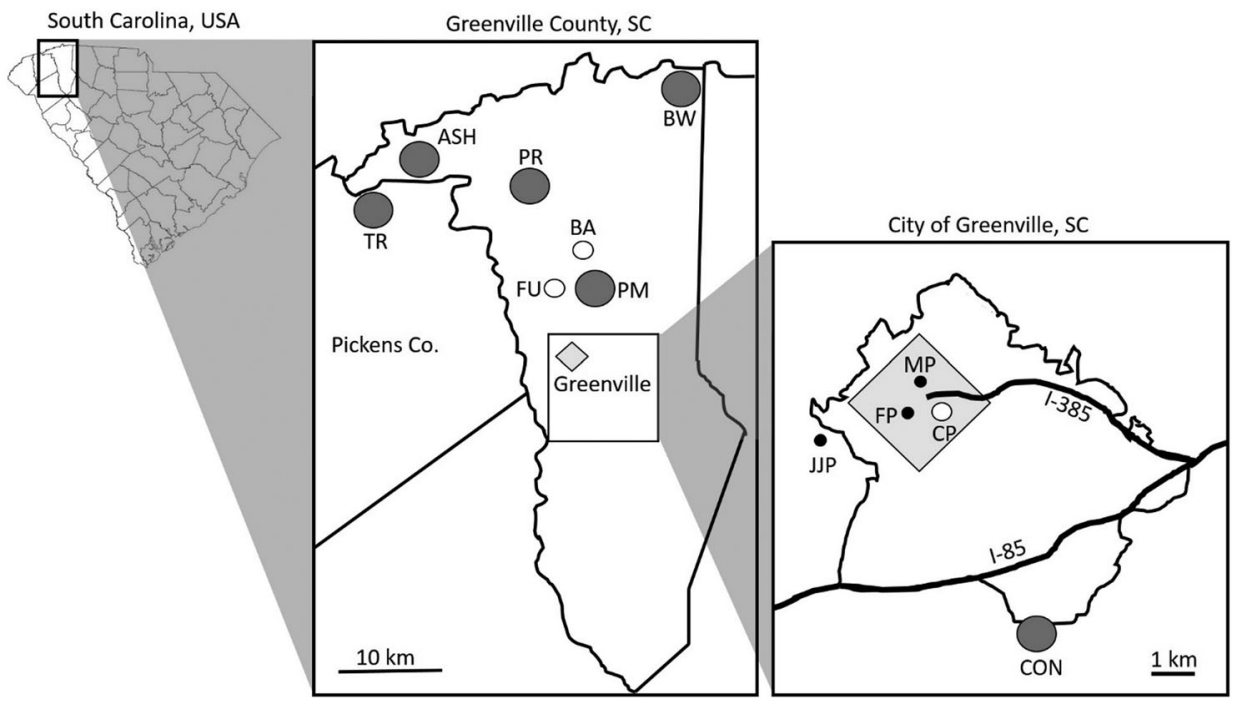

Figure 1. The location of sites used in this study in Greenville and Pickens Counties, SC, and within the city limits of Greenville, SC (inset; gray diamond is the downtown area): Ashmore Heritage Trust Preserve (ASH), Bunched Arrowhead Heritage Trust Preserve (BA), Blue Wall Nature Conservancy Preserve (BW), Cleveland Park (CP), Lake Conestee Nature Preserve (CON), Falls Park (FP), Furman University (FU), Joe Jackson Park (JJP), McPherson Park (MP), Paris Mountain State Park (PM), Pleasant Ridge County Park (PR), Table Rock State Park (TR). The size of the park is indicated as "small" ( $<10$ ha, $)$, "medium" $(10<\mathrm{x}<100 \mathrm{ha}, \bigcirc)$, or "large" ( $>100$ ha, $\bigcirc$ ). 


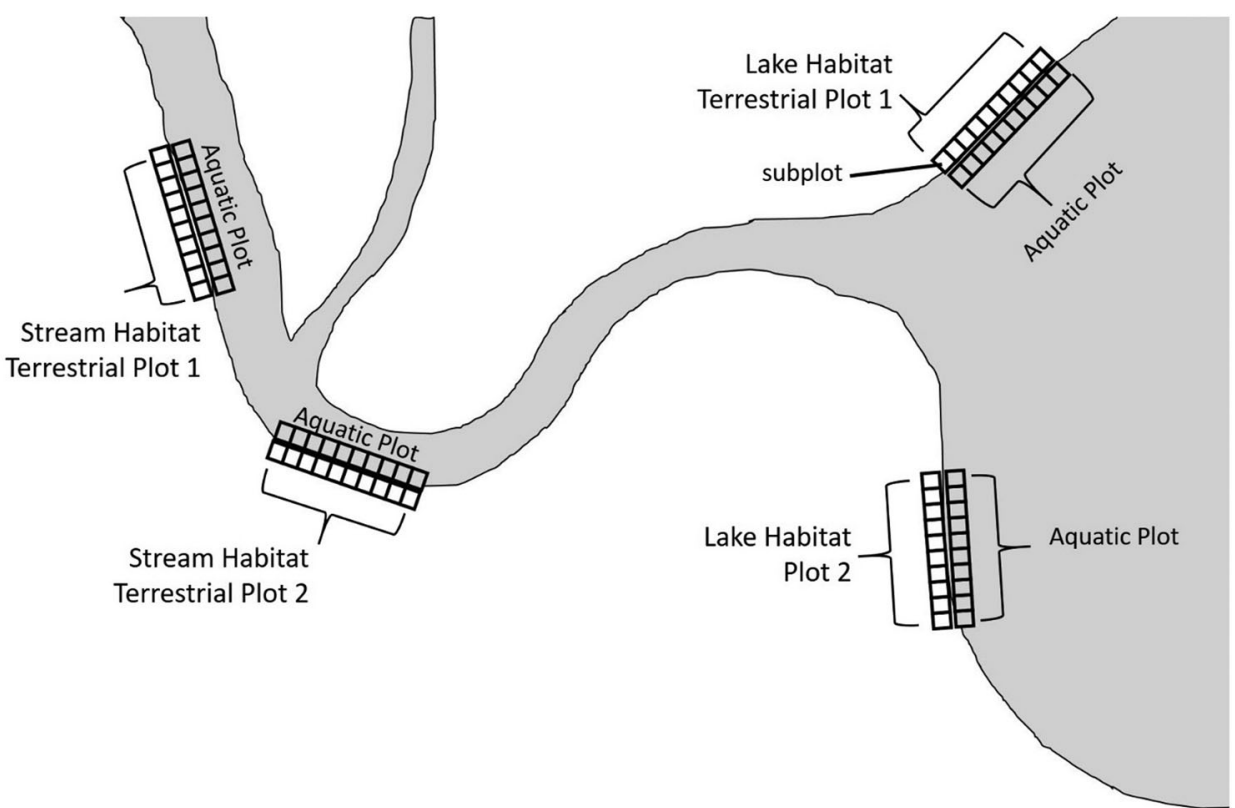

Figure 2. A schematic diagram of the relationships between terrestrial and aquatic subplots and plots at different habitats at the same site.

Table 1. The distribution of 37 sampling plots across five habitats at 12 sites in Greenville Co. and Pickens Co., SC, USA: lake (14 plots), stream (18 plots), pond (2 plots), river (2 plots), and swamp (1 plot).

\begin{tabular}{|c|c|c|c|c|c|}
\hline Site & Lake & Stream & Pond & River & Swamp \\
\hline Ashmore Heritage Trust Preserve & 2 & 2 & & & \\
\hline Blue Wall Preserve & 2 & 2 & & & \\
\hline Bunched Arrowhead Heritage Trust Preserve & & 1 & 1 & & \\
\hline Cleveland Park & & 2 & & & \\
\hline Falls Park & & 1 & & & 1 \\
\hline Furman University & 2 & 2 & 1 & & \\
\hline Lake Conestee Nature Preserve & 2 & & & 1 & 1 \\
\hline McPherson Park & & 2 & & & \\
\hline Paris Mountain State Park & 2 & 2 & & & \\
\hline Pleasant Ridge County Park & 2 & 2 & & & \\
\hline Joe Jackson Park & & 2 & & & \\
\hline Table Rock State Park & 2 & & & & \\
\hline
\end{tabular}

software (Rasband, 2018). In addition, the adjacent $2 \mathrm{~m} \times 2 \mathrm{~m}$ subplot of aquatic habitat was also described by estimating the percent cover of different types of substrate (mud, sand, rocks, bedrock), and noting the dominant types of detritus (none, muck, coarse organics, debris), and aquatic vegetation (none, moss, algae, rooted macrophytes). Describing terrestrial and aquatic habitats by the percent cover of substrate and vegetation types is a common methodology (Clark $\&$ Samways, 1996; Goertzen \& Suhling, 2013). The dominant vegetation type in each terrestrial subplot (greatest percent cover), and the dominant substrate type in each aquatic subplot (greatest percent cover) were also recorded as categorical variables. In addition, substrate and vegetational diversity indices were computed using Simpson's reciprocal diversity index $\left(D=1 / \Sigma\left(\mathrm{p}_{\mathrm{i}}^{2}\right)\right)$, where $\mathrm{p}_{\mathrm{i}}=$ percent cover of the $\mathrm{i}^{\text {th }}$ sediment or vegetation type. To describe environmental conditions at the plot scale, percent cover values in subplots were summed across each $2 \mathrm{~m} \times 20 \mathrm{~m}$ terrestrial and aquatic plot and total percent cover for each category was recalculated at the plot 
scale. Habitats were characterized as pond, lake, swamp, stream, or river, and the width of the riparian zone (none, $<5 \mathrm{~m}, 5-10 \mathrm{~m}, 10-15 \mathrm{~m},>20 \mathrm{~m}$ ) was also noted. At the largest spatial scale, the landscape around each plot was described by calculating the percent cover of different landforms (National Land Cover Dataset classification) in circular plots (radius $=500 \mathrm{~m}$ ) centered on each plot, using ArcGIS. Sites were also categorized as small ( $<5 \mathrm{ha})$, medium (10-100 ha) or large (>100 ha; Figure 1).

\section{Odonate sampling}

We surveyed odonates three times at each plot from June to August 2017, between $1100 \mathrm{~h}$ and $1400 \mathrm{~h}$, in accordance with the minimum survey recommendations of Foote and Rice Hornung (2005) and Chovanec, Schindler, Waringer, and Wimmer (2015). During each survey, we counted the number of dragonflies of each species that perched within a subplot during a three-minute observation period. Timed plot sampling is becoming a common method in odonate surveys (Harabiš, 2017; Harabiš \& Dolný, 2015). Individuals that could not be identified with binoculars were caught by net after the timed interval and identified in hand, following the methods of Silva et al. (2010). Since many species of dragonflies ("flyers") patrol their territories on the wing and rarely land, we also recorded: (1) species that flew through a plot or landed at a different subplot during the 30-minute observation period, and (2) species seen at the habitat but not within the plot. No attempt was made to distinguish or count individuals of these supplemental species; their presence was notes solely for species richness analyses.

\section{Statistical analyses}

The data from the three odonate surveys were pooled, and the total odonate abundance, species richness, and Simpson's reciprocal diversity were calculated per subplot $(\mathrm{N}=370)$. Variation in odonate abundance, richness, and diversity across sites, habitats within sites, and plots within habitats were assessed with nested general linear models. Akaike information criterion (AIC) models were used to determine the "best subset" of habitat parameters that explained the variation in abundance, richness, and diversity at the subplot, plot, and habitat scales. For these analyses, the vegetational and aquatic substrate parameters, site, habitat type, and landscape parameters were included in the models; only variables with a strong $(p<0.01)$ effect are reported. At the plot and habitat scales, the percent covers in terrestrial and aquatic subplots were combined and recalculated for that larger scale (combining subplot values to generate plot values, and combining plot values to generate habitat values). Likewise, community descriptors were aggregated and recalculated at each scale. Although abundance simply sums from subplot to plot to habitat, Simpson's diversity values at larger scales are not simply the average of smaller scale values, because the identities of species and their combined relative abundances change from subsample to subsample. For example, one plot may contain 10 individuals of a single species, and have a Simpson's diversity value $=1.0$. The second plot in that habitat might have 10 individuals of a different species, and also have a plot diversity $=1.0$. However, the diversity value for the habitat, recalculated across the abundance of all species in the habitat (10 individuals of species 1 and 10 individuals of species 2), would equal 2, not the average of the plot values (1.0). In addition, species richness values at the plot scale included species that flew through the plot during the three 30-minute observation periods, and species richness values at the habitat scale included additional species seen in the habitat outside the plots. As such, although abundance values at larger scales are sums of values at the subplot scale, richness and diversity values are independent measures computed at these larger scales. 
At the largest scale, sites ranged in size from large state parks within contiguous blocks of natural landscape to small stream courses within urban areas, and they varied from containing one habitat type to several (Table 1). We conducted an ANOVA to describe the effects of site size (small, medium or large) and habitat variability (number of habitat types at a site) on species richness at each site. For these analyses, species richness included all species seen perching in subplots, flying through plots, and observed in sampled habitats at each site. ANOVA, Pearson correlations, and $\chi^{2}$ tests were used to describe factors that had significant effects $(p<0.01)$ in the AIC models. All ANOVA and Akaike analyses were performed using SPSS software (IBM, 2015).

We also compared the composition of these communities in nestedness analyses. We used the presence-absence matrix of species occurring in each habitat type to compute a nestedness value using the NODF method (Almeida-Neto, Guimarães, Guimarães, Jr, Loyola, \& Ulrich, 2008), and compared this to the mean value of 50 null models which assigned species to habitats based on the proportional occurrence of each species, and the proportional richness values of habitats, using the "Nestedness for Dummies" program (Strona \& Fattorini, 2014; Strona, Galli, Seveso, Montano, \& Fattorini, 2014). We also conducted a nestedness analysis comparing the species composition across the 12 sites, using the same analytical parameters.

\section{Results}

The mean abundance, species richness, and Simpson's diversity of odonates/subplot varied significantly between habitats and sites (Table 2a). Mean abundance/subplot was greater at ponds than at all other habitats, and all indices were significantly greater at lake habitats than in stream habitats (Table 2b). Habitat was also one of the best predictors of all three community indices in AIC models at this scale (Table 3a). Other environmental parameters were also important. Odonate abundance was negatively affected by wider riparian zones and more barren land in the landscape; richness and diversity declined with increasing grassland cover in the landscape and were higher next to aquatic subplots with no detritus than coarse detritus or muck. However,

Table 2. (a) Nested general linear models describing variation in dragonfly abundance, species richness, and Simpson's diversity in $2 \mathrm{~m} \times 2 \mathrm{~m}$ subplots among plots, habitats, and 12 sites in Greenville Co. and Pickens Co., SC, USA (statistically significant effects $(p>0.05)$ are bold-faced), and (b) mean comparisons among habitats (means followed by the same letter are not significantly different, Bonferroni $t$-tests). Species richness and Simpson's diversity analyses only included subplots that contained at least one individual $(\mathrm{N}=200)$, whereas abundance analyses included all subplots $(\mathrm{N}=370)$.

a) Nested general linear models

\begin{tabular}{|c|c|c|c|c|c|c|c|c|c|}
\hline \multirow[b]{2}{*}{ Source } & \multicolumn{3}{|c|}{ Abundance } & \multicolumn{3}{|c|}{ Species richness } & \multicolumn{3}{|c|}{ Simpson's diversity } \\
\hline & df & Wald $\chi^{2}$ & $p$ & df & Wald $\chi^{2}$ & $p$ & df & Wald $\chi^{2}$ & $p$ \\
\hline Site & 11 & 90.65 & 0.0001 & 11 & 35.44 & 0.0001 & 11 & 38.41 & 0.0001 \\
\hline $\mathrm{Hab}$ (Site) & 10 & 79.52 & 0.0001 & 10 & 37.15 & 0.0001 & 10 & 37.84 & 0.0001 \\
\hline Plot(Hab(Site)) & 15 & 41.36 & 0.0001 & 11 & 21.62 & 0.028 & 11 & 19.11 & 0.059 \\
\hline
\end{tabular}

b) Mean comparisons across habitats

\begin{tabular}{|c|c|c|c|c|c|c|c|c|c|}
\hline \multirow[b]{2}{*}{ Habitat } & \multicolumn{3}{|c|}{ Abundance } & \multicolumn{3}{|c|}{ Species richness } & \multicolumn{3}{|c|}{ Simpson's diversity } \\
\hline & $\mathrm{N}$ & $\overline{\mathrm{x}} \pm 1 \mathrm{se}$ & & $\mathrm{N}$ & $\overline{\mathrm{x}} \pm 1 \mathrm{se}$ & & $\mathrm{N}$ & $\overline{\mathrm{x}} \pm 1 \mathrm{se}$ & \\
\hline Lake & 140 & $1.82 \pm 0.13$ & $\mathrm{~b}$ & 101 & $2.02 \pm 0.08$ & $\mathrm{a}$ & 101 & $1.93 \pm 0.08$ & $\mathrm{a}$ \\
\hline Pond & 20 & $2.95 \pm 0.33$ & $\mathrm{a}$ & 19 & $1.58 \pm 0.19$ & $\mathrm{ab}$ & 19 & $1.50 \pm 0.17$ & $a b$ \\
\hline Swamp & 10 & $1.20 \pm 0.47$ & $\mathrm{bc}$ & 5 & $1.60 \pm 0.37$ & $\mathrm{ab}$ & 5 & $1.54 \pm 0.33$ & $\mathrm{ab}$ \\
\hline River & 20 & $1.00 \pm 0.33$ & $\mathrm{bc}$ & 12 & $1.47 \pm 0.24$ & $\mathrm{ab}$ & 12 & $1.44 \pm 0.22$ & $a b$ \\
\hline Stream & 180 & $0.49 \pm 0.16$ & $\mathrm{c}$ & 63 & $1.08 \pm 0.26$ & $\mathrm{~b}$ & 63 & $1.07 \pm 0.23$ & $\mathrm{~b}$ \\
\hline
\end{tabular}


Table 3. Summary of AIC models predicting dragonfly abundance, species richness, and Simpson's diversity in (a) subplots, (b) plots, and (c) habitats, as a function of variation in terrestrial (T), aquatic (A), and landscape (L) parameters. For each model, the model accuracy (adjusted $\mathrm{r}^{2}$ ), and the importance values (proportion of model variance $=\operatorname{Imp}$ ), significance levels $(p<0.01)$, and the direction of the relationship $(+/-)$ of significant predictors are listed. Relationships for categorical variables are presented in the text.

a) Subplot scale

\begin{tabular}{|c|c|c|c|c|c|c|c|c|c|}
\hline \multirow{3}{*}{$\begin{array}{l}\text { Model accuracy: } \\
\text { Predictor }\end{array}$} & \multicolumn{3}{|c|}{ Abundance } & \multicolumn{3}{|c|}{ Species richness } & \multicolumn{3}{|c|}{ Simpson's diversity } \\
\hline & \multicolumn{3}{|c|}{$\mathrm{r}^{2}=0.315(\mathrm{~N}=370)$} & \multicolumn{3}{|c|}{$\mathrm{r}^{2}=0.266(\mathrm{~N}=200)$} & \multicolumn{3}{|c|}{$\mathrm{r}^{2}=0.279(\mathrm{~N}=200)$} \\
\hline & Imp & $p$ & $+1-$ & $\operatorname{Imp}$ & $p$ & $+1-$ & Imp & $p$ & $+1-$ \\
\hline Habitat type & 0.171 & 0.0001 & & 0.500 & 0.0001 & & 0.494 & 0.0001 & \\
\hline $1^{\circ}$ Detritus (A) & & & & 0.328 & 0.0001 & & 0.322 & 0.0001 & \\
\hline Grassland (L) & & & & 0.103 & 0.005 & - & 0.090 & 0.005 & - \\
\hline Site & 0.392 & 0.0001 & & & & & & & \\
\hline Riparian zone (T) & 0.238 & 0.0001 & & & & & & & \\
\hline Barren land (L) & 0.090 & 0.0001 & - & & & & & & \\
\hline
\end{tabular}

b) Plot scale

\begin{tabular}{|c|c|c|c|c|c|c|c|c|c|}
\hline \multirow{3}{*}{$\frac{\text { Model accuracy: }}{\text { Predictor }}$} & \multicolumn{3}{|c|}{ Abundance } & \multicolumn{3}{|c|}{ Species richness } & \multicolumn{3}{|c|}{ Simpson's diversity } \\
\hline & \multicolumn{3}{|c|}{$\mathrm{r}^{2}=0.685(\mathrm{~N}=37)$} & \multicolumn{3}{|c|}{$\mathrm{r}^{2}=0.686(\mathrm{~N}=37)$} & \multicolumn{3}{|c|}{$\mathrm{r}^{2}=0.622(\mathrm{~N}=33)$} \\
\hline & $\operatorname{Imp}$ & $p$ & $+1-$ & Imp & $p$ & $+1-$ & Imp & $p$ & $+1-$ \\
\hline Habitat & 0.583 & 0.0001 & & 0.725 & 0.0001 & & & & \\
\hline$\%$ turf $(\mathrm{T})$ & 0.198 & 0.0001 & + & & & & & & \\
\hline$\%$ short herb. (T) & 0.123 & 0.001 & + & & & & & & \\
\hline Substrate Div. (A) & & & & & & & 0.344 & 0.0001 & - \\
\hline Water (L) & & & & & & & 0.31 & 0.0001 & + \\
\hline Grassland (L) & & & & & & & 0.150 & 0.006 & - \\
\hline$\%$ short woody $(\mathrm{T})$ & & & & & & & 0.145 & 0.007 & - \\
\hline
\end{tabular}

c) Habitat scale

\begin{tabular}{|c|c|c|c|c|c|c|c|c|c|}
\hline \multirow{3}{*}{$\begin{array}{l}\text { Model accuracy: } \\
\text { Predictor }\end{array}$} & \multicolumn{3}{|c|}{ Abundance } & \multicolumn{3}{|c|}{ Species richness } & \multicolumn{3}{|c|}{ Simpson's diversity } \\
\hline & \multicolumn{3}{|c|}{$\mathrm{r}^{2}=0.405(\mathrm{~N}=22)$} & \multicolumn{3}{|c|}{$\mathrm{r}^{2}=0.865(\mathrm{~N}=22)$} & \multicolumn{3}{|c|}{$\mathrm{r}^{2}=0.948(\mathrm{~N}=22)$} \\
\hline & $\operatorname{Imp}$ & $p$ & $+1-$ & $\operatorname{Imp}$ & $p$ & $+1-$ & Imp & $p$ & $+1-$ \\
\hline Habitat & 1.000 & 0.011 & & 0.619 & 0.0001 & & & & \\
\hline$\% \operatorname{mud}(\mathrm{A})$ & & & & 0.247 & 0.001 & + & & & \\
\hline Water (L) & & & & & & & 0.407 & 0.0001 & + \\
\hline Substrate Div. (A) & & & & & & & 0.274 & 0.0001 & - \\
\hline $1^{\circ}$ Detritus (A) & & & & & & & 0.239 & 0.0001 & \\
\hline Grassland (L) & & & & & & & 0.041 & 0.003 & - \\
\hline
\end{tabular}

Note: Substrate Div. = Substrate diversity.

riparian zones and detritus were not independent of habitat type. The type of detritus varied significantly across habitats $\left(\chi^{2}=166.162, \mathrm{df}=12, p<0.0001\right)$. In particular, subplots scored as "no detritus" - the detrital type with the greatest mean richness and diversity - were twice as common in ponds $(50.0 \%)$ and lakes $(27.1 \%)$ than the other habitat types $(10.0 \%$ or less). Likewise, habitats also varied with respect to riparian zone classifications $\left(\chi^{2}=81.162\right.$, $\mathrm{df}=16$, $p<0.0001$ ). Lakes and ponds were usually in open areas with no riparian zone or isolated trees (64.3\% of lake subplots, $52.6 \%$ of pond subplots), but streams and rivers were in wooded areas with wider riparian zones ( $>10 \mathrm{~m}$ ) or forest $(50.8 \%$ of stream subplots, $100 \%$ of river subplots).

At the plot scale, habitat was again the primary predictor of abundance and richness (Table $3 \mathrm{~b}$ ). Mean ( $\pm 1 \mathrm{sd}$ ) abundance/plot tracked subplot patterns, with odonates significantly more abundant at ponds $(29.5 \pm 2.12)$ than streams $(7.1 \pm 6.7)$; other habitats were intermediate and not different from these extremes (ANOVA, $p<0.0001$, Tukey post-hoc comparisons). Although 
richness values were recomputed at the plot scale, they also followed the subplot pattern, with mean $( \pm 1 \mathrm{sd})$ species richness in lake plots $(11.1 \pm 4.4)$ significantly greater than in stream plots $(2.6 \pm 1.2)$, and other habitats intermediate and not different from these extremes (ANOVA, $p=0.0001$; Tukey multiple comparison test). Mean abundance/plot was also predicted by the $\%$ cover of turfgrass and short herbaceous vegetation in plots (Table $3 \mathrm{~b}$ ). Although there were no statistically significant differences between habitats in the mean percent cover of these variables (ANOVA, $p>0.05$ ), lakes had the greatest mean percent cover of turfgrass $(21.1 \%)$, three times greater than the next highest value (streams $=6.6 \%)$. Odonate diversity was predicted by a different set of variables (Table $3 b$ ). The diversity of aquatic substrates/plot was a negative predictor of odonate diversity (Table 3b). Again, however, this varied significantly between habitats (ANOVA, $p<0.0001$ ); stream plots had greater mean substrate diversity $(1.84 \pm 0.50)$ than lakes $(1.0 \pm 0.10)$ and ponds $(1.0 \pm 0.0)$. Likewise, odonate diversity was predicted by the amount of open water in the landscape (Table $3 \mathrm{~b}$ ). Curiously, this did not differ significantly among habitats (ANOVA, $p=0.094)$, though lake plots $(6.69 \%)$ exceeded other habitats $(0.7 \%-0.0)$. After accounting for these variables, diversity was negatively associated with grassland cover in the landscape, and percent cover of short woody vegetation; neither of which were related to differences among habitats (ANOVA, $p>0.05$ ).

At the habitat scale, abundance and species richness were again best explained by differences in the habitat (Table 2c), with lakes harboring significantly more species, on average, than streams (lake: $16.9 \pm 4.7$, stream: $4.8 \pm 2.15$; ANOVA, $p<0.0001$; other habitats intermediate and not different from these extremes, Tukey multiple comparisons). Richness was also associated with the percent cover of mud substrate (Table $2 \mathrm{c}$ ), which also varied significantly among habitats (ANOVA, $p<0.0001$ ). The percent cover of mud, pooled across plots within habitats, was significantly greater in ponds $(100 \%)$ and lakes $(71.2 \%)$ than in rivers $(5.2 \%)$ and streams (5.0\%; Tukey multiple comparison tests). Mean ( $\pm 1 \mathrm{sd}$ ) odonate diversity showed the same pattern replicated from subplot to plot; it was greatest in lakes $(5.1 \pm 1.7)$, significantly greater than streams $(1.5 \pm 0.8$; ANOVA, $p<0.0001$; other habitats intermediate and not different from these extremes, Tukey multiple comparison test). Odonate diversity was predicted by a combination of variables that were significant on smaller scales. Again, substrate diversity and $1^{\circ}$ detritus varied across habitats in a manner consistent with habitat differences in diversity. The species using streams, rivers, ponds, and swamps were significantly nested subsets of the species found at lakes (NODF subscore for species composition similarities: 77.045, $\mathrm{z}=6.899, p<0.0001$ ). Lakes contained 40 of the 45 species found at one of the other habitats and 17 species found nowhere else (Table 4). Although differences in sampling effort undoubtedly contributed to differences in total species encountered, species-poor lentic habitats (streams and rivers $=20$ plots) were sampled more than species-rich lotic habitats (lakes, ponds, swamps $=17$ plots).

Lastly, at the largest "site" scale, we analyzed the effects of site size and habitat number on the species richness per site. The size of the site - and not the number of different habitats (or plots sampled) at a site - had a significant effect on species richness at a site (Table 5). Large sites had significantly more species, on average, than small sites (Figure 3, Tukey mean comparison test, $\mathrm{p}=0.05$ ). The sites exhibited significantly nested species composition structure (NODF subscore for species composition similarities: 70.628, $\mathrm{z}=9.454, \mathrm{p}<0.001$ ), with small sites containing low-diversity subsets of communities found in progressively larger sites (Table 6).

\section{Discussion}

The abundance, species richness, and diversity of adult odonates responded to environmental variation at all spatial scales, from meters to kilometers. But at all scales, habitat type and its 
Table 4. Species occurrence patterns across habitats $(1=$ present; $0=$ not observed $)$. Communities are significantly nested across habitats (see text).

\begin{tabular}{|c|c|c|c|c|c|c|}
\hline Species & 总 & 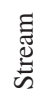 & $\begin{array}{l}\overparen{0} \\
\stackrel{0}{0}\end{array}$ & 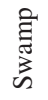 & $\stackrel{\dot{D}}{a}$ & 䒕 \\
\hline Species richness & 40 & 20 & 16 & 11 & 10 & \\
\hline Argia fumipennis (Burmeister) & 1 & 1 & 1 & 1 & 1 & 5 \\
\hline Ischnura posita (Hagen) & 1 & 1 & 1 & 1 & 1 & 5 \\
\hline Libellula incesta Hagen & 1 & 1 & 1 & 1 & 1 & 5 \\
\hline Erythemis simplicicollis Say & 1 & 0 & 1 & 1 & 1 & 4 \\
\hline Libellula vibrans Fabricius & 1 & 1 & 0 & 1 & 1 & 4 \\
\hline Argia apicalis (Say) & 1 & 1 & 1 & 0 & 1 & 4 \\
\hline Argia tibialis (Rambur) & 1 & 1 & 1 & 0 & 1 & 4 \\
\hline Nehalennia integricollis Calvert & 1 & 1 & 0 & 1 & 1 & 4 \\
\hline Plathemis lydia (Drury) & 1 & 1 & 1 & 1 & 0 & 4 \\
\hline Pachydiplax longipennis (Burmeister) & 1 & 1 & 1 & 1 & 0 & 4 \\
\hline Calopteryx maculata (Palisot) & 0 & 1 & 1 & 0 & 1 & 3 \\
\hline Celithemis fasciata Kirby & 1 & 0 & 1 & 1 & 0 & 3 \\
\hline Perithemis tenera (Say) & 1 & 1 & 0 & 1 & 0 & 3 \\
\hline Libellula luctuosa Burmeister & 1 & 0 & 1 & 1 & 0 & 3 \\
\hline Libellula auripennis Burmeister & 1 & 1 & 1 & 0 & 0 & 3 \\
\hline Argia sedula (Hagen) & 1 & 0 & 0 & 0 & 1 & 2 \\
\hline Tramea carolina (L.) & 1 & 0 & 1 & 0 & 0 & 2 \\
\hline Tramea lacerata Hagen & 1 & 0 & 1 & 0 & 0 & 2 \\
\hline Epitheca princeps Hagen & 1 & 0 & 1 & 0 & 0 & 2 \\
\hline Libellula cyanea Fabricius & 1 & 0 & 1 & 0 & 0 & 2 \\
\hline Hagenius brevistylus Selys & 1 & 1 & 0 & 0 & 0 & 2 \\
\hline Didymops transversa (Say) & 1 & 1 & 0 & 0 & 0 & 2 \\
\hline Dromogomphus spinosus Selys & 1 & 1 & 0 & 0 & 0 & 2 \\
\hline Phanogomphus exilis (Selys) & 1 & 1 & 0 & 0 & 0 & 2 \\
\hline Argia moesta (Hagen) & 0 & 1 & 0 & 0 & 0 & 1 \\
\hline Cordulegaster maculata Selys & 0 & 1 & 0 & 0 & 0 & 1 \\
\hline Phanogomphus lividus (Selys) & 0 & 1 & 0 & 0 & 0 & 1 \\
\hline Tachopteryx thoreyi (Selys) & 0 & 1 & 0 & 0 & 0 & 1 \\
\hline Anax junius (Drury) & 1 & 0 & 0 & 0 & 0 & 1 \\
\hline Anax longipes Hagen & 1 & 0 & 0 & 0 & 0 & 1 \\
\hline Celithemis bertha Williamson & 1 & 0 & 0 & 0 & 0 & 1 \\
\hline Celithemis elisa (Hagen) & 1 & 0 & 0 & 0 & 0 & 1 \\
\hline Celithemis ornata (Rambur) & 1 & 0 & 0 & 0 & 0 & 1 \\
\hline Dythemis velox Hagen & 1 & 0 & 0 & 0 & 0 & 1 \\
\hline Epitheca cynosura (Say) & 1 & 0 & 0 & 0 & 0 & 1 \\
\hline Enallagma aspersum (Hagen) & 1 & 0 & 0 & 0 & 0 & 1 \\
\hline Enallagma daeckii (Calvert) & 1 & 0 & 0 & 0 & 0 & 1 \\
\hline Enallagma divagans Selys & 1 & 0 & 0 & 0 & 0 & 1 \\
\hline Enallagma geminatum Kellicott & 1 & 0 & 0 & 0 & 0 & 1 \\
\hline Enallagma traviatum Selys & 1 & 0 & 0 & 0 & 0 & 1 \\
\hline Epiaeschna heros (Fabricius) & 1 & 0 & 0 & 0 & 0 & 1 \\
\hline Erythrodiplax minuscula (Rambur) & 1 & 0 & 0 & 0 & 0 & 1 \\
\hline Ladona deplanata (Rambur) & 1 & 0 & 0 & 0 & 0 & 1 \\
\hline Lestes inaequalis Walsh & 1 & 0 & 0 & 0 & 0 & 1 \\
\hline Pantala flavescens (Fabricius) & 1 & 0 & 0 & 0 & 0 & 1 \\
\hline
\end{tabular}

environmental correlates were the primary determinants of community structure. In general, lake communities had more individuals, more species, and greater diversity than stream communities, regardless of the scale of analysis. This is not surprising; all habitats have communities of zygopterans, but lakes and ponds are also used by a rich diversity of libellulid species. It is important to appreciate, of course, that all lakes and ponds in this study are man-made impoundments. So, as in other cases (Goertzen \& Suhling, 2015; Simaika et al., 2016; Suh \& Samways, 


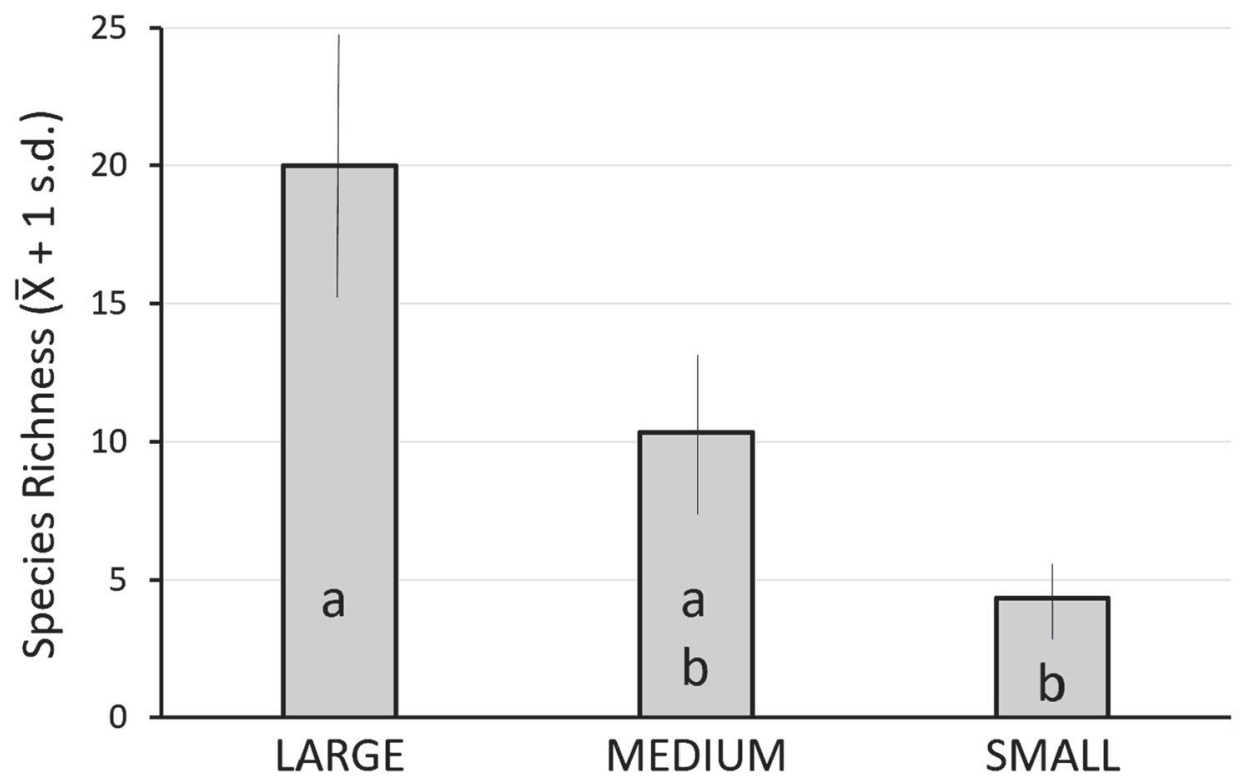

Figure 3. A comparison of mean ( $\pm 1 \mathrm{sd}$ ) species richness values in large ( $>100$ ha), medium (10 ha $<\mathrm{x}<100$ ha), and small $(<10$ ha) sites. Values labeled with the same letter are not significantly different (Tukey mean comparisons test, $p=0.05)$.

Table 5. ANOVA describing the effects of site size and habitat variation on the species richness values in sites.

\begin{tabular}{lcrrc}
\hline Source & df & Mean square & \multicolumn{1}{c}{ F } & $p$ \\
\hline Size & 2 & 179.286 & 11.076 & 0.023 \\
Habitats & 2 & 23.440 & 1.448 & 0.354 \\
Size $\times$ Habitats & 3 & 9.150 & 0.565 & 0.608 \\
Error & 4 & 16.188 & & \\
\hline
\end{tabular}

2005), returning lakes and ponds to the landscape - lost as a consequence of wetland conversion (Dahl 1990, 1999) and beaver eradication (Naiman, Melillo, \& Hobbie, 1986) over the last 200 years in this region - had a beneficial effect on odonate communities.

At all scales, characteristics of the bank vegetation and the aquatic substrate were important predictors of odonate community structure. These results are consistent with other studies documenting the importance of substrate characteristics (Brasil et al., 2014) and shoreline vegetation (Niba \& Samways, 2006; Remsburg \& Turner, 2009), probably because these variables are important to adult dragonflies selecting oviposition sites (substrate) and perches (vegetation). In this study, however, the effects of these variables probably reflect differences between habitats. Lakes and ponds had muddier bottoms, lower substrate diversity, less detritus, thinner riparian zones, and higher percent cover of turfgrasses and short herbaceous vegetation than rivers or streams. So, as in other studies (Luke et al., 2017; Oliviera-Júnior et al., 2015; Remsburg et al., 2008; Seidu et al., 2017), abundance, richness, and diversity increased as habitats changed from shaded streams exploited by a small set of zygopterans to open habitats used by a greater number of zygopteran and libellulid species. Indeed, the particular species found at streams and rivers were also found at ponds and lakes, creating significantly nested-subset patterns among habitats. Although some streams were in fairly pristine areas, several were in small habitat islands in urban areas. Differences in species tolerances to anthropogenic impacts can cause initially 
Table 6. Species occurrence patterns across sites $(1=$ present; $0=$ not observed $)$. Communities are significantly nested across sites, in a manner consistent with habitat size (see text).

\begin{tabular}{|c|c|c|c|c|c|c|c|c|c|c|c|c|c|}
\hline Species & 金 & 咅 & $\underset{\sim}{\mathbb{2}}$ & 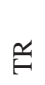 & Z & $\sum$ & $\underset{\emptyset}{\overleftarrow{\emptyset}}$ & 只 & $\frac{3}{3}$ & $\stackrel{0}{\Sigma}$ & 党 & 点 & $\stackrel{\tilde{\omega}}{\omega}$ \\
\hline Site size: & $\mathrm{L}$ & $\mathrm{L}$ & $\mathrm{L}$ & $\mathrm{L}$ & $\mathrm{L}$ & $\mathrm{L}$ & M & M & M & $\mathrm{S}$ & $S$ & $\mathrm{~S}$ & \\
\hline Species richness: & 26 & 24 & 23 & 18 & 17 & 16 & 16 & 16 & 7 & 6 & 5 & 2 & \\
\hline Argia fumipennis & 1 & 1 & 1 & 1 & 1 & 1 & 1 & 1 & 1 & 1 & 1 & 1 & 12 \\
\hline Libellula incesta & 1 & 1 & 1 & 1 & 1 & 1 & 1 & 1 & 1 & 1 & 0 & 0 & 10 \\
\hline Ischnura posita & 1 & 1 & 1 & 1 & 1 & 0 & 1 & 1 & 1 & 0 & 1 & 0 & 9 \\
\hline Calopteryx maculata & 1 & 1 & 1 & 0 & 1 & 1 & 1 & 1 & 0 & 1 & 0 & 1 & 9 \\
\hline Pachydiplax longipennis & 1 & 1 & 1 & 1 & 1 & 1 & 1 & 1 & 0 & 1 & 0 & 0 & 9 \\
\hline Argia tibialis & 1 & 1 & 0 & 1 & 1 & 1 & 1 & 0 & 1 & 1 & 1 & 0 & 9 \\
\hline Celithemis fasciata & 1 & 1 & 1 & 1 & 1 & 1 & 1 & 1 & 0 & 0 & 0 & 0 & 8 \\
\hline Erythemis simplicicollis & 1 & 1 & 1 & 1 & 1 & 1 & 1 & 1 & 0 & 0 & 0 & 0 & 8 \\
\hline Libellula luctuosa & 1 & 1 & 1 & 1 & 1 & 1 & 1 & 1 & 0 & 0 & 0 & 0 & 8 \\
\hline Libellula vibrans & 1 & 1 & 0 & 1 & 1 & 1 & 1 & 1 & 0 & 0 & 0 & 0 & 7 \\
\hline Tramea carolina & 1 & 1 & 1 & 0 & 0 & 1 & 1 & 1 & 0 & 0 & 0 & 0 & 6 \\
\hline Perithemis tenera & 1 & 0 & 0 & 1 & 1 & 1 & 0 & 1 & 0 & 1 & 0 & 0 & 6 \\
\hline Plathemis lydia & 1 & 1 & 0 & 0 & 1 & 1 & 1 & 1 & 0 & 0 & 0 & 0 & 6 \\
\hline Argia apicalis & 0 & 1 & 0 & 1 & 1 & 0 & 1 & 0 & 1 & 0 & 1 & 0 & 6 \\
\hline Celithemis elisa & 1 & 0 & 1 & 1 & 0 & 0 & 0 & 1 & 0 & 0 & 0 & 0 & 4 \\
\hline Tramea lacerata & 1 & 1 & 0 & 1 & 0 & 0 & 0 & 1 & 0 & 0 & 0 & 0 & 4 \\
\hline Epitheca princeps & 1 & 1 & 0 & 0 & 0 & 0 & 1 & 1 & 0 & 0 & 0 & 0 & 4 \\
\hline Libellula cyanea & 1 & 1 & 0 & 1 & 0 & 0 & 1 & 0 & 0 & 0 & 0 & 0 & 4 \\
\hline Hagenius brevistylus & 1 & 1 & 1 & 0 & 0 & 1 & 0 & 0 & 0 & 0 & 0 & 0 & 4 \\
\hline Nehalennia integricollis & 0 & 0 & 1 & 0 & 1 & 0 & 0 & 0 & 1 & 0 & 1 & 0 & 4 \\
\hline Libellula auripennis & 1 & 0 & 1 & 0 & 0 & 0 & 1 & 0 & 0 & 0 & 0 & 0 & 3 \\
\hline Phanogomphus exilis & 1 & 1 & 1 & 0 & 0 & 0 & 0 & 0 & 0 & 0 & 0 & 0 & 3 \\
\hline Epitheca cynosura & 0 & 1 & 1 & 0 & 0 & 0 & 0 & 0 & 0 & 0 & 0 & 0 & 2 \\
\hline Ladona deplanata & 0 & 1 & 1 & 0 & 0 & 0 & 0 & 0 & 0 & 0 & 0 & 0 & 2 \\
\hline Anax longipes & 1 & 0 & 1 & 0 & 0 & 0 & 0 & 0 & 0 & 0 & 0 & 0 & 2 \\
\hline Didymops transversa & 0 & 1 & 1 & 0 & 0 & 0 & 0 & 0 & 0 & 0 & 0 & 0 & 2 \\
\hline Celithemis bertha & 0 & 0 & 1 & 1 & 0 & 0 & 0 & 0 & 0 & 0 & 0 & 0 & 2 \\
\hline Argia sedula & 0 & 0 & 0 & 1 & 1 & 0 & 0 & 0 & 0 & 0 & 0 & 0 & 2 \\
\hline Argia moesta & 1 & 0 & 0 & 0 & 0 & 0 & 0 & 0 & 1 & 0 & 0 & 0 & 2 \\
\hline Enallagma daeckii & 1 & 0 & 1 & 0 & 0 & 0 & 0 & 0 & 0 & 0 & 0 & 0 & 2 \\
\hline Enallagma divagans & 0 & 1 & 0 & 0 & 0 & 1 & 0 & 0 & 0 & 0 & 0 & 0 & 2 \\
\hline Enallagma geminatum & 1 & 1 & 0 & 0 & 0 & 0 & 0 & 0 & 0 & 0 & 0 & 0 & 2 \\
\hline Celithemis ornata & 0 & 0 & 1 & 0 & 0 & 0 & 0 & 0 & 0 & 0 & 0 & 0 & 1 \\
\hline Epiaeschna heros & 0 & 0 & 0 & 0 & 1 & 0 & 0 & 0 & 0 & 0 & 0 & 0 & 1 \\
\hline Anax junius & 0 & 1 & 0 & 0 & 0 & 0 & 0 & 0 & 0 & 0 & 0 & 0 & 1 \\
\hline Pantala flavescens & 0 & 0 & 0 & 1 & 0 & 0 & 0 & 0 & 0 & 0 & 0 & 0 & 1 \\
\hline Erythrodiplax minuscula & 1 & 0 & 0 & 0 & 0 & 0 & 0 & 0 & 0 & 0 & 0 & 0 & 1 \\
\hline Cordulegaster maculata & 0 & 0 & 1 & 0 & 0 & 0 & 0 & 0 & 0 & 0 & 0 & 0 & 1 \\
\hline Dromogomphus spinosus & 0 & 0 & 0 & 0 & 0 & 1 & 0 & 0 & 0 & 0 & 0 & 0 & 1 \\
\hline Phanogomphus lividus & 0 & 0 & 0 & 0 & 0 & 0 & 0 & 1 & 0 & 0 & 0 & 0 & 1 \\
\hline Tachopteryx thoreyi & 0 & 0 & 1 & 0 & 0 & 0 & 0 & 0 & 0 & 0 & 0 & 0 & 1 \\
\hline Enallagma aspersum & 1 & 0 & 0 & 0 & 0 & 0 & 0 & 0 & 0 & 0 & 0 & 0 & 1 \\
\hline Enallagma traviatum & 0 & 0 & 0 & 0 & 0 & 1 & 0 & 0 & 0 & 0 & 0 & 0 & 1 \\
\hline Lestes inaequalis & 0 & 0 & 0 & 0 & 1 & 0 & 0 & 0 & 0 & 0 & 0 & 0 & 1 \\
\hline Dythemis velox & 0 & 0 & 0 & 1 & 0 & 0 & 0 & 0 & 0 & 0 & 0 & 0 & 1 \\
\hline
\end{tabular}

heterogeneous assemblages of tolerant and intolerant species to "decay" to progressively smaller sets of progressively more tolerant species over time or across space, creating communities with a nested-subset structure (Worthen, 1996, 2003; Worthen, Cuddy, Haney, Turgeon, \& Andersen, 2001). With the exception of the lotic specialists Cordulegaster maculata and Argia moesta, it seems that the species dominating streams and rivers in our study are broadly tolerant habitat 
generalists. However, our sampling was not exhaustive and was strongly biased towards common species.

Landscape parameters were also important predictors of odonate structure at all scales. The percent cover of open water had a positive relationship with diversity at the plot and habitat scale, again as a proxy for the greater diversity in lakes than streams. However, the percent cover of grasslands was a negative predictor of richness (at the plot scale) and diversity (at all scales), and did not differ significantly among habitat types. This may reflect anthropogenic habitat alterations due to urbanization and agriculture (Brasil et al., 2014; Carvalho, Pinto, Oliveira-Júnior, $\&$ Juen, 2013). However, rather than habitat variation, habitat size seemed to be a more important determinant of community structure. The sites used in this study ranged from large expanses of intact natural habitat to small isolates in urban settings, and contained up to four different habitat types. Species richness increased with site size, consistent with predictions from island biogeography (MacArthur \& Wilson, 1967), but was not significantly affected by the number of habitats sampled at each site. There were strong patterns of nested-subset structure across habitat types and sites, as well. The species found in low diversity communities, which were typically stream habitats in small urban sites, were also found in progressively more species-rich sites, even those with only a lake habitat.

The primacy of site size over habitat variability is counter-intuitive, and contrasts with Hart, Bowker, Tarboton, and Downs (2014) who found that large areas with multiple habitats hosted more species than single habitats. In our study, however, these variables are not completely independent. Of the three small sites, two only contained streams and the third had a stream and river. So, small sites not only had low habitat diversity - they were disproportionately represented by the most species-poor habitat types in our study. One large site, Table Rock State Park, also had just one habitat type and might therefore be expected to have lower species richness, except the habitat was a species-rich lake. So, our unbalanced design may have obscured the relationship between habitat variation and total species richness.

In conclusion, differences in habitat type and habitat size - and covarying environmental conditions - were the primary determinants of odonate community structure in this study. Anthropogenic changes to the landscape were also implicated. Urbanization may have already caused non-random extinction of riverine species in small urban streams, which harbored low diversity communities dominated by broadly tolerant generalists. However, another effect of human action on dragonfly communities in this region, at this time when humans are attempting to protect and restore environmentally degraded areas, has been the positive influence of returning lakes and ponds to the landscape. It is critical, however, that these impoundments not jeopardize critical habitat for riverine species threatened by urbanization. Future studies will examine how land use in the region affects odonate communities in these streams and rivers.

\section{Acknowledgements}

We thank Dr John Quinn for his statistical help with Akaike modeling. We thank the South Carolina Department of Parks Recreation and Tourism, the South Carolina Department of Natural Resources Heritage Trust Division, Greenville County Parks and Recreation, Lake Conestee Nature Preserve, The Nature Conservancy, and the City of Greenville for allowing us to sample at these sites. This research was supported by a grant from The Furman Advantage to MGC and a Furman Standard grant to WBW.

\section{References}

Almeida-Neto, M., Guimarães, P., Guimarães, P. R. Jr, Loyola, R. D., \& Ulrich, W. (2008). A consistent metric for nestedness analysis in ecological systems: reconciling concept and measurement. Oikos, 117(8), 1227-1239. doi: 10.1111/j.2008.0030-1299.16644.x 
Brasil, L. S., Batista, J. D., Giehl, N. F. S., Valadão, M. B. X., Santos, J. O., \& Dias-Silva, K. (2014). Environmental integrity and damselfly species composition in Amazonian streams at the "arc of deforestation" region, Mato Grosso, Brazil. Acta Limnologica Brasiliensia, 26(3), 278-287. doi: 10.1590/S2179-975X2014000300007

Bried, J. T., \& Samways, M. J. (2015). A review of odonatology in freshwater applied ecology and conservation science. Freshwater Science, 34, 1023-1031. doi: 10.1086/682174.

Bush, A., Theischinger, G., Nipperess, D., Turak, E., \& Hughes, L. (2013). Dragonflies: climate canaries for river management. Diversity and Distributions, 19, 86-97. doi: 10.1111/ddi.12007.

Carvalho, F. G., Pinto, N. S., Oliveira-Júnior, J. M. B., \& Juen, L. 2013. Effects of marginal vegetation removal on Odonata communities. Acta Limnologica Brasiliensia, 25(1), 1018. doi:10.1590/S2179-975X2013005000013.

Chovanec, A., Schindler, M., Waringer, J., \& Wimmer, R. (2015). The dragonfly association index (Insecta: Odonata)— a tool for the type-specific assessment of lowland rivers. River Research and Applications, 31, 627-638. doi: $10.1002 /$ rra.2760.

Chovanec, A., \& Waringer, J. (2001). Ecological integrity of river-floodplain systems - assessment by dragonfly surveys (Insecta: Odonata). Regulated Rivers: Research \& Management, 17, 493-507. doi: 10.1002/rrr.664.

Clark, T. E., \& Samways, M. J. (1996). Dragonflies (Odonata) as indicators of biotype quality in the Kruger National Park, South Africa. Journal of Applied Ecology, 33, 1001-1012. doi: 10.2307/2404681.

Collins, S. D., \& McIntyre, N. E. (2017). Extreme loss of diversity of riverine dragonflies in the northeastern U.S. is predicted in the face of climate change. Bulletin of American Odonatology, 12(2), 7-19.

Córdoba-Aquilar, A. (2008). Dragonflies and damselflies: model organisms for ecological and evolutionary research. Oxford, UK: Oxford University Press. 290 p. doi:10.1093/acprof:oso/9780199230693.001.0001.

Dahl, T. E. (1990). Wetlands-Losses in the United States, 1780's to 1980's: Washington, D.C., U.S. Fish and Wildlife Service Report to Congress, 13 p. Retrieved February 25, 2020 from: https//nrm.dfg.ca.gov/FileHandler.ashx? DocumentID $=7699$.

Dahl, T. E. (1999). South Carolina's wetlands — status and trends 1982-1989. U.S. Department of the Interior, Fish and Wildlife Service, Washington, D.C. 58 pp. Retrieved February 25, 2020 from: http://www.fws.gov/wetlands/Documents/South-Carolinas-Wetlands-Status-and-Trends-1982-1989.pdf.

De Marco, P., Nóbrega, C. C., de Souza, R. A., \& Neiss, U. G. (2015). Modeling the distribution of a rare Amazonian odonate in relation to future deforestation. Freshwater Science, 34, 1123-1132. doi:10.1086/682707.

Dolný, A., \& Harabiš, F. (2012). Underground mining can contribute to freshwater biodiversity conservation: allogenic succession forms suitable habitats for dragonflies. Biological Conservation, 145, 109-117. doi: 10.1016/j.biocon.2011.10.020.

Dolný, A., Harabiš, F., Bárta, D., Lhota, S., \& Drozd, P. (2013). Aquatic insects indicate terrestrial habitat degradation: changes in taxonomical structure and functional diversity of dragonflies in tropical rainforest of East Kalimantan. Tropical Zoology, 25, 141-157. doi:10.1080/03946975.2012.717480.

Foote, A. L., \& Rice Hornung, C. L. (2005). Odonates as biological indicators of grazing effects on Canadian prairie wetlands. Ecological Entomology, 30, 273-283. doi: 10.1111/j.0307-6946.2005.00701.x

Goertzen, D., \& Suhling, F. (2013). Promoting dragonfly diversity in cities: Major determinants and implications for urban pond design. Journal of Insect Conservation, 17, 399-409. doi:10.1007/s10841-012-9522-z.

Goertzen, D., \& Suhling, F. (2019). Urbanization versus other land use: Diverging effects on dragonfly communities in Germany. Biodiversity Research, 25, 38-47. doi:10.1111/ddi.12820.

Goertzen, D., Suhling, F., Leather, S. R., \& Sahlén, G. (2015). Central European cities maintain substantial dragonfly species richness - a chance for biodiversity conservation? Insect Conservation and Diversity, 8, $238-246$. doi:10.1111/icad.12102.

Golfieri, B., Hardersen, S., Maiolini, B., \& Surian, N. (2016). Odonates as indicators of the ecological integrity of the river corridor: development and application of the Odonate River Index (ORI) in northern Italy. Ecological Indicators, 61, 234-247. doi:10.1016/j.ecolind.2015.09.022.

Hafiane, M., Hamzaoui, D., Attou, F., Bouchelouche, D., Arab, A., Alfarhan, A. H., \& Samraoui, B. (2016). Anthropogenic impacts and their influence on the spatial distribution of the Odonata of Wadi El Harrach (North-Cental Algeria). Revue d'Ecologie, 71(3), 239-249. Retrieved February 25, 2020 from:https://www.researchgate.net/publication/305651332_Anthropogenic_impacts_and_their_influence_on_the_ spatial_distribution_of_the_Odonata_of_Wadi_el_Harrach_North-Central_Algeria

Harabiš, F. (2017). Does the management surrounding terrestrial habitats increase the tendency of odonates to leave aquatic habitats? Biodiversity and Conservation, 26, 2155-2167. doi: 10.1007/s10531-017-1350-8.

Harabiš, F., \& Dolný, A. (2015). Odonates need natural disturbances: how human-induced dynamics affect the diversity of dragonfly assemblages. Freshwater Science, 34, 1050-1057. doi:10.1086/682234.

Hart, L. A., Bowker, M. B., Tarboton, W., \& Downs, C. T. (2014). Species composition, distribution and habitat types of Odonata in the iSimangaliso Wetland Park, KwaZuluNatal, South Africa and the associated conservation implications, PLoS One, 9, e92588. doi:10.1371/journal.pone.0092588.

Hassall, C. (2015). Odonata as candidate macroecological barometers for global climate change. Freshwater Science, 34 , 1040- 1049. doi:10.1086/682210.

IBM Corp. (2015). IBM SPSS Statistics for Windows, Version 23.0. Armonk, NY, IBM Corp.

Kadoya, T., Suda, S., Nishihiro, J., \& Washitani, I. (2008). Procedure for predicting the trajectory of species recovery based on the nested species pool information: dragonflies in a wetland restoration site as a case study. Restoration Ecology, 16, 397-406. doi: 10.1111/j.1526-100X.2007.00314.x. 
Luke, S. H., Dow, R. A., Butler, S., Khen, C. V., Aldridge, D. C., Foster, W. A., \& Turner, E. C. (2017). The impact of habitat disturbance on adult and larval dragonflies (Odonata) in rainforest streams in Sabah, Malaysian Borneo. Freshwater Biology, 62, 491-506. doi:10.1111/fwb.12880.

MacArthur, R. H., \& Wilson, E. O. (1967). The theory of island biogeography. Princeton, NJ: Princeton University Press. doi: $10.1515 / 9781400881376$.

Maynou, X., Martín, R., \& Aranda, D. (2017). The role of small secondary biotopes in a highly fragmented landscape as habitat and connectivity providers for dragonflies (Insecta: Odonata). Journal of Insect Conservation, 21(3), 517-530. doi:10.1007/s10841-017-9992-0.

Monteiro-Júnior, C. S., Couceiro, S. R. M., Hamada, N., \& Juen, L. (2013). Effect of vegetation removal for road building on richness and composition of Odonata communities in Amazonia, Brazil. International Journal of Odonatology, 16(2), 135-144. doi:10.1080/13887890.2013.764798.

Monteiro-Júnior, C. S., Juen, L., \& Hamada, N. (2014). Effects of urbanization on stream habitats and associated adult dragonfly and damselfly communities in central Brazilian Amazonia. Landscape and Urban Planning, 127, 28-40. doi:10.1016/j.landurbplan.2014.03.006.

Nagy, H. B., László, Z., Szabó, F., Szöcs, L., Dévai, G., \& Tóthmérész, B. (2019). Landscape-scale terrestrial factors are also vital in shaping odonata assemblages of watercourses. Scientific Reports, 9, 18196. doi:10.1038/s41598-019-54628-7.

Naiman, R. J., Melillo, J. M., \& Hobbie, J. E. (1986). Ecosystem alteration of boreal forest streams by beaver (Castor Canadensis). Ecology, 67(5), 1254-1269. doi:10.2307/1938681.

Niba, A. S., \& Samways, M. J. (2006). Development of the concept of 'Core Resident Species' for quality assurance of an insect reserve. Biodiversity and Conservation, 15, 4181-4196. doi:10.1007/s10531-005-3554-6.

Oertli, B. (2008). The use of dragonflies in the assessment and monitoring of aquatic habitats. In: Córdoba-Aguilar, A. (Ed.) Dragonflies and Damselflies: model organisms for ecological and evolutionary research (pp. 79-95) Oxford, UK: Oxford University Press. doi:10.1093/acprof:oso/9780199230693.003.0007.

Oliveira-Júnior, J. M. B., Dias-Silva, K., Teodósio, M. A., \& Juen, L. (2019). The response of Neotropical dragonflies (Insecta: Odonata) to local and regional abiotic factors in small streams of the Amazon. Insects, $10,446$. doi:10.3390/insects10120446.

Oliveira-Júnior, J. M. B., Shimano, Y., Gardner, T. A., Hughes, R. M., De Marco, J. P., \& Juen, L. (2015). Neotropical dragonflies (Insecta: Odonata) as indicators of ecological condition of small streams in the eastern Amazon. Austral Ecology, 40, 733-744. doi:10.1111/aec.12242.

Palita, S. K., Jena, S. K., \& Debat, S. (2016). Odonate diversity along different habitats of Koraput district, Odisha, India. Journal of Entomology and Zoology Studies, 4(3), 40-47. Retrieved February 25, 2020 from: http://www.entomoljournal.com/archives/2016/vol4issue3/PartA/4-3-4.pdf.

Rasband, W. S. (2018). ImageJ, U. S. National Institutes of Health, Bethesda, Maryland, USA, https://imagej.nih.gov/ij/.

Remsburg, A. J. (2007). Aquatic and terrestrial vegetation influence lacustrine dragonfly (order Odonata) assemblages at multiple life stages. PhD Thesis, University of Wisconsin, Madison, Wisconsin. Retrieved February 25, 2020 from: https://pdfs.semanticscholar.org/8a71/65d09637d089a59eed5f978b2613994602ec.pdf

Remsburg, A. J., Olson, A. C., \& Samways, M. J. (2008). Shade alone reduces adult dragonfly (Odonata: Libellulidae) abundance. Journal of Insect Behavior, 21, 460-468. doi:10.1007/s10905-008-9138-z.

Remsburg, A. J., \& Turner, M. (2009). Aquatic and terrestrial drivers of dragonfly (Odonata) assemblages within and among north-temperate lakes. Journal of the North American Benthological Society, 28(1), 44-56. doi:10.1899/08-004.1.

Renner, S., Sahlén, G., \& Périco, E. (2016). Testing dragonflies as species richness indicators in a fragmented subtropical Atlantic forest environment. Neotropical Entomology, 45, 231-239. doi:10.1007/s13744-015-0355-9.

Rodrigues, M. E., Roque, O. F., Quintero, J. M. O., Pena, J. C. C., Sousa, D. C., \& De Marco, P. (2016). Nonlinear responses in damselfly community along a gradient of habitat loss in a savanna landscape. Biological Conservation, 194, 113-120. doi:10.1016/j.biocon.2015.12.001.

Sahlén, G., \& Ekestubbe, K. (2001). Identification of dragonflies (Odonata) as indicators of general species richness in borealforest lakes. Biodiversity and Conservation, 10, 673-690. doi:10.102 3/A:1016681524097.

Sato, M., Kohmatsu, Y., Yuma, M., \& Tsubaki, Y. (2008). Population genetic differentiation in three sympatric damselfly species in a highly fragmented urban landscape (Zygoptera: Coenagrionidae). Odonatologica, 37, 131-144. Retrieved February 25, 2020 from: http://natuurtijdschriften.nl/download?type = document\&docid = 592621.

Schindler, M., Fesl, C., \& Chovanec, A. (2003). Dragonfly associations (Insecta: Odonata) in relation to habitat variables: a multivariate approach. Hydrobiologia, 497, 169-180. doi:10.1023/A:1025476220081.

Seidu, I., Danquah, E., Nsor, C. A., Kwarteng, D. A., \& Lancaster, L. T. (2017). Odonata community structure and patterns of land use in the Atewa Range Forest Reserve, Eastern Region (Ghana), International Journal of Odonatology, 20(3-4), 173-189. doi:10.1080/13887890.2017.1369179.

Silva, D. P., De Marco, P., \& Resende, D. C. (2010). Adult odonate abundance and community assemblage measures as indicators of stream ecological integrity: A case study. Ecological Indicators, 10(3), 744-752. doi: 10.1016/j.ecolind.2009.12.004

Simaika, J. P., \& Samways, M. J. (2009). An easy-to-use index of ecological integrity for prioritizing freshwater sites and for assessing habitat quality. Biodiversity and Conservation, 18, 1171-1185. doi: 10.1007/s10531-008-9484-3.

Simaika, J. P., Samways, M. J., \& Frenzel, P. P. (2016). Artificial ponds increase local dragonfly diversity in a global biodiversity hotspot. Biodiversity and Conservation, 25, 1921-1935. doi: 10.1007/s10531-016-1168-9.

Stoks, R., Debecker, S., Van, K. D., \& Janssens, L. (2015). Integrating ecology and evolution in aquatic toxicology: insights from damselflies. Freshwater Science, 34, 1032-1039. doi:10.1086/682571. 
Strona, G., \& Fattorini, S. (2014). Nestedness for dummies. Retrieved February 25, 2020 from: https://ecosoft. alwaysdata.net/.

Strona, G., Galli, P., Seveso, D., Montano, S., \& Fattorini, S. (2014). Nestedness for dummies (NeD): A user-friendly web interface for exploratory nestedness analyses. Journal of Statistical Software, 59, Code Snippet 3, 1-9. doi:10.18637/jss.v059.c03.

Suh, A. N., \& Samways, M. J. (2005). Significance of temporal changes when designing a reservoir for conservation of dragonfly diversity. Biodiversity and Conservation, 14, 165-178. doi:10.1007/s10531-005-3652-5.

Suhonen, J., Suutari, E., Kaunisto, K. M., \& Krams, I. (2013). Patch area of macrophyte Stratioites aloides as a critical resource for declining dragonfly Aeshna viridis. Journal of Insect Conservation, 17, 393-398. doi:10.1007/s10841-012-9521-0.

Villalobos-Jiménez, G., Dunn, A. M., \& Hassall, C. (2016). Dragonflies and damselflies (Odonata) in urban systems: A review. European Journal of Entomology, 113, 217-232. doi: 10.14411/eje.2016.027.

Wood, J. M., \& Quinn, J. E. (2016). Local and landscape metrics identify opportunities for conserving cavity-nesting birds in a rapidly urbanizing ecoregion. Journal of Urban Ecology, 2, 1-10. doi:10.1093/jue/juw003.

Worthen, W. B. (1996). Membership patterns and nested subset analyses: Basic descriptors for community ecology. Oikos, 76, 417-426. doi:10.2307/3546335.

Worthen W. B. (2003). Nested-subset structure of larval odonate assemblages in the Enoree River basin, USA. International Journal of Odonatology, 6(1), 79-89. doi:10.1080/13887890.2003.10510452.

Worthen, W. B., Cuddy, C., Haney, D. C., Turgeon, V. L., \& Andersen, C. B. (2001). The effect of an industrial spill on the macrofauna of a South Carolina stream: physiological to community-level responses. Journal of Freshwater Ecology, 3, 467-477. doi:10.1080/02705060.2001.9663835. 